\title{
Pattern of seismic deformation in the Western Mediterranean
}

\author{
Silvia Pondrelli \\ Istituto Nazionale di Geofisica, Roma, Italy
}

\begin{abstract}
The seismic deformation of the Western Mediterranean was studied with the aim of defining the strain pattern that characterizes the Africa-Eurasia plate boundary in this area. Within different sections along the boundary the NUVEL1A plate motion model and geodetic data. A stable seismological data. The results were compared with where only Africa and Eurasia plates are involved. In thisreement was found along Northern Africa to Sicily, boundary correspond to variations in the prevailing geo this zone it is evident that changes in the strike of the of seismic with respect to total expected deforme geometry of deformation, tectonic features and in the percentage (Central to Southern Apennines, Eastern Alps and the Teometry of deformation of periadriatic sections and with regional geological features. Seismicity Eastern Adriatic area) agrees well with VLBI measurements expected deformation. Only in the Sicily Stricity seems to account for low rates, from $3 \%$ to $31 \%$, of total ratio reach a higher value (79\%). If the amount characterized by extensional to strike slip deformation, does the years are probably not representative of the recurreformation deduced from seismicity seems low, because 90 pattern we obtain from cumulative moment tensors is more cycle of the Western Mediterranean, the strain global plate motion models and better identifies lower more representative of the kinematics of this area than
\end{abstract}

Key words deformation-seismicity-geodynamicsMediterranean

\section{Introduction}

The Western Mediterranean geodynamics is substantially characterized by the presence of the active boundary between Africa, Eurasia and Adria plates. Along this sinuous margin, which runs from Gibraltar Strait all along Northern Africa, Northern Sicily, the Apennines, Alps and Dynarides chains, the tectonic setting and direction of motion change continuously (fig. 1). This shape is the heritage of a complex geologic evolution to which not only major plate

Mailing address: Dr. Silvia Pondrelli, Istituto Nazionale di Geofisica, Via di Vigna Murata 605, 00143 Roma, Italy; e-mail: pondrix@ingrm.it motion contributed, but also the presence of various smaller blocks (Dewey et al., 1989). A short part of the boundary is certainly affected by active subduction (Southern Tyrrhenian Sea, dotted line in fig. 1), while elsewhere the margin is characterised by subducted lithosphere (Spakman et al., 1993; Piromallo and Morelli, 1997) and some intermediate depth and moderate energy seismicity is present (e.g., Northern Apennines, Selvaggi and Amato, 1992).

The moment tensor summation method (Kostrov, 1974; Jackson and McKenzie, 1988), here applied, gives important information on active deformation. During the last 15 years, many studies proposed the computation of seismic deformation and most of them applied similar theoretical methods to the Mediterranean area (Jackson and McKenzie, 1988; Ekström and England, 1989; Papazachos and Kiratzi, 1992; Westaway, 1992; Pondrelli et al., 1995). The results often differ mainly because they 


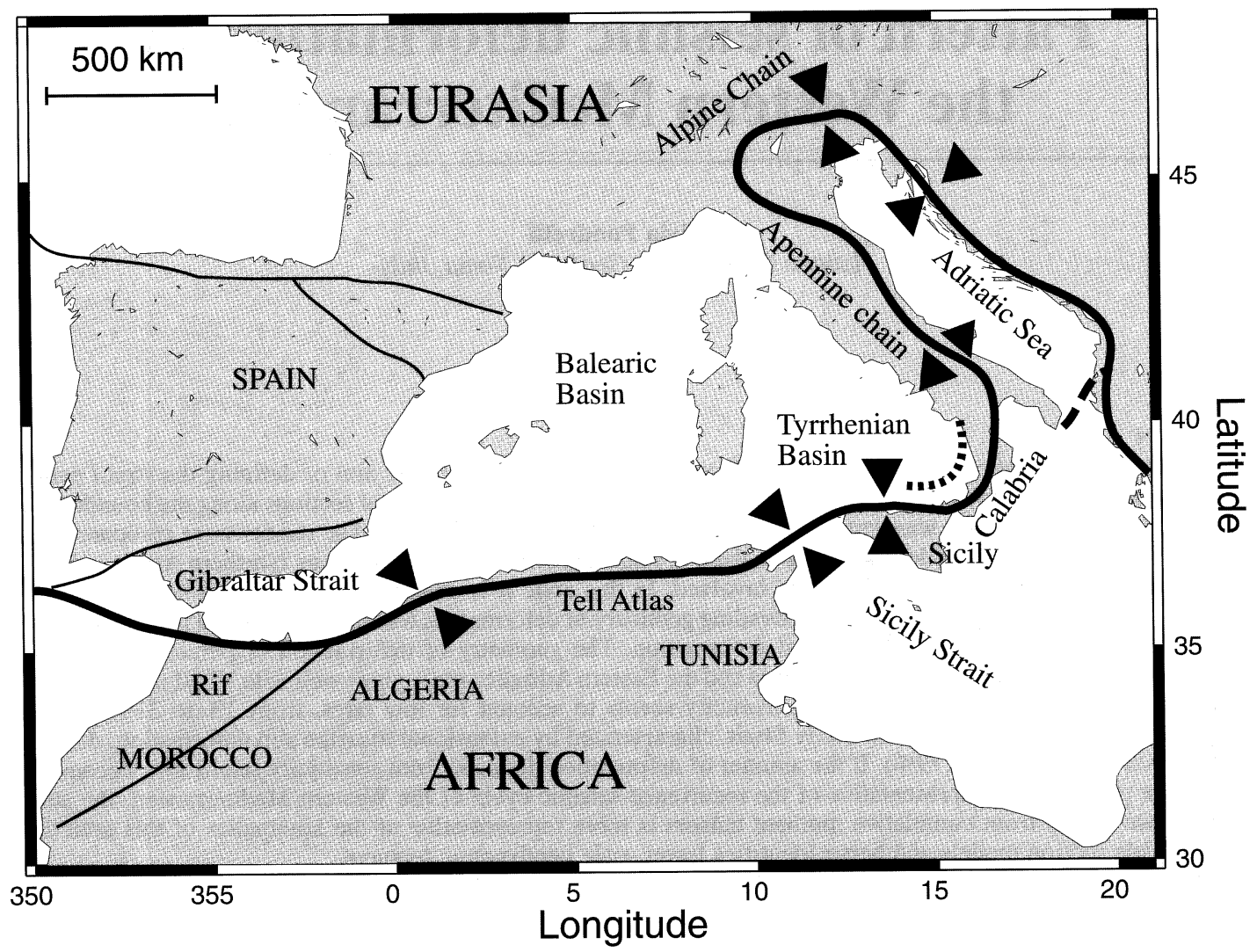

Fig. 1. Sketch map of the tectonic setting of the Western Mediterranean. The black line represents the active boundary between the Africa, Eurasia and Adria plates. The dashed line is one of the hypothesised boundaries between the Africa and Adria plates. The dotted line shows where the subduction is active. Thin lines are other tectonic lineaments. Black arrows show the main directions of deformation.

were obtained using different parameters in defining the dimensions of studied areas or seismological data sets that cover different time spans. However, only events with $M \geq 4.5$ are considered representative of the regional stress and thus useful in seismic deformation studies.

From the moment tensor summation we obtain the geometry of seismic deformation, its amplitude and an evaluation of the relative seismic velocity of plates (Jackson and McKenzie, 1988). The geometry of deformation describes how each zone is deforming; together with tectonic setting and other geological data it can be fundamental for the study of the kinematics of present day motion. Seismic strain, strain rate and velocity could be compared with a wide variety of data obtained from other studies, like plate motion models, geologic and geodetic measurements, to evaluate the percentage of deformation accommodated by seismicity (Jackson and McKenzie, 1988; Pondrelli et al., 1995; Anzidei et al., 1997; Ward, 1998). From moment tensor summation any rotation, if present, occurring within each studied section, cannot be evaluated and it should be deduced from paleomagnetic or geodetic measurements.

The Western Mediterranean can be divided into two areas with respect to the plates in- 


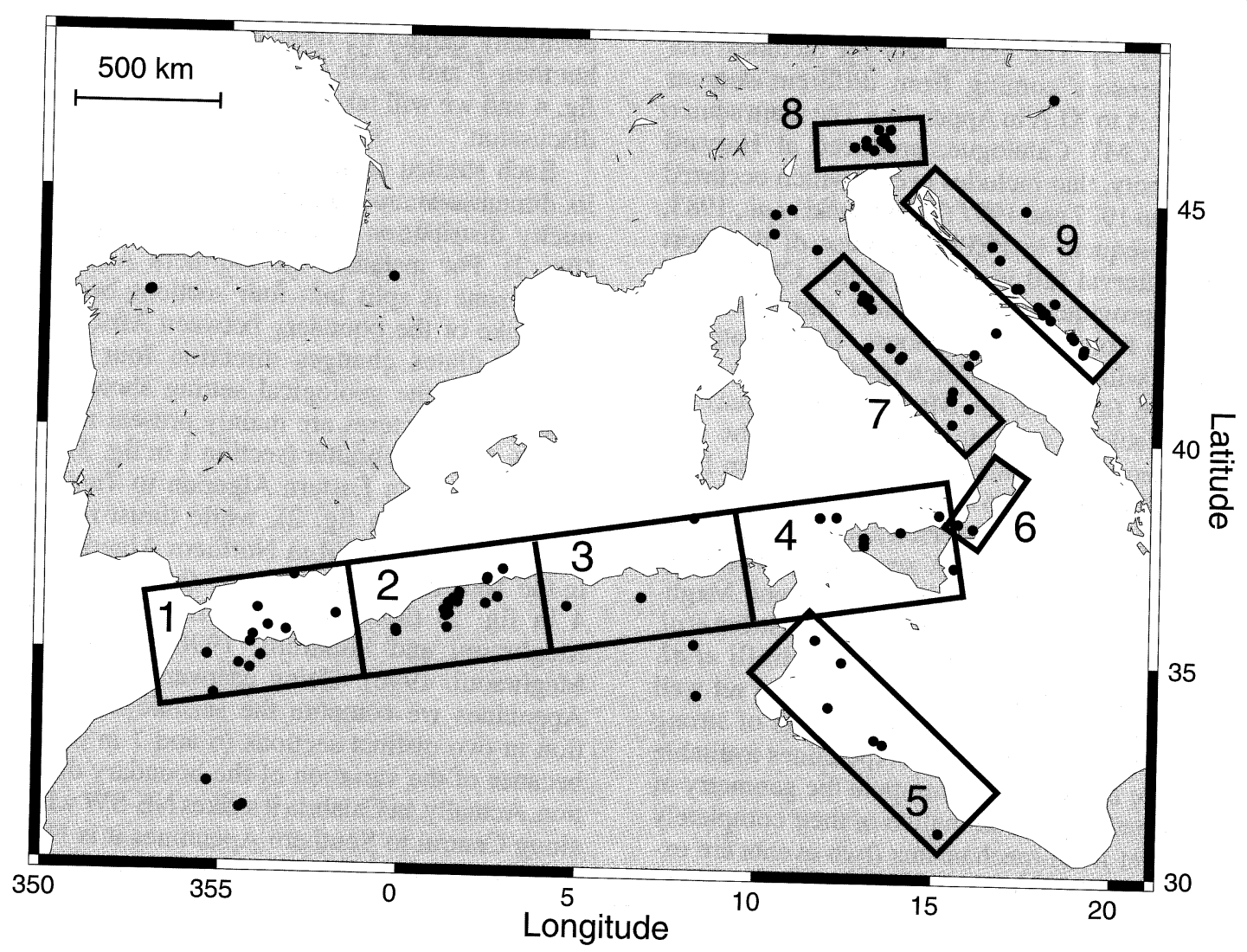

Fig. 2. Map of seismic events used in this study (see table I.A to XI.A of Appendix). Each box is the volume 1 = Gibraltar Strin evaluate seismic deformation. Their dimensions and orientations are shown in table I. Sections: $7=$ Central to Southern Apennines; $8=$ Friuli; $9=$ Eastern Adriatic.
7 .

volved along the boundary: from Gibraltar Strait to Sicily only the Africa and Eurasia plates interact, while east of the Messina Strait the Adria plate motion also contributes to present deformation. In this paper we apply the summation along different segments of this complex boundary (fig. 2). The Northern Africa-Sicily zone is split into four sections characterised by different tectonic settings. The Apennine chain is split into three areas: a northern and a southern part of the chain and the Calabria region. Along the Alpine chain, only the eastern part (Friuli region), being the one affected by strong seismicity, is considered. The Eastern Adriatic area is the last section studied. These zones are obviously strictly related, but we should study them individually because of the variation of strike direction along the boundary and to recognize, where possible, variations in the deformation along the boundary itself.

\section{Seismological data and parametrization of sections}

For this study, we utilise only crustal events with $M \geq 4.5$, considered representative of the regional stress field and of the crustal deforma- 
tion (fig. 2). The entire data set includes moment tensors coming from different sources (table I.A to XI.A in Appendix). The main source is the CMT Catalogue, produced at Harvard University, that includes events which occurred between 1977 and 1997 (Dziewonski et al., 1983; all subsequent in PEPI). Because of the short time interval (20 years) for which CMT Catalogue provides data, we select some moment tensors from another database. Data related to events with $M \geq 6.0$ which occurred from 1908 to 1976 (all over the Mediterranean area) are from Jackson and McKenzie (1988); the moment tensor of events which occurred from 1908 to 1994 with $M \geq 4.5$ are from McKenzie (1972) (Periadriatic area), Anderson and Jackson (1987) (the 1968 Belice, Sicily, sequence), Westaway (1990) (Sicily Strait region), Morel and Meghraoui(1996)(Northwestern Africa), Ekström etal. (1998) (Central Apennines), Pondrelli et al. (1998) (Friuli region). Though the data set well increased, representing now 90 years of strong seismicity, in the Northern Apennines available data are inadequate to compute the geometry of deformation: the summation of their completely different focal mechanisms (two events are extensional and two are strike-slip) does not explain which pattern of deformation would prevail in this area. These events are however included in fig. 2 (and in table VIII.A of the Appendix) with some other events (table XI.A) which occurred outside the zones considered strictly related to boundary deformation. They obviously cannot be used in the summations, but their $P$ and $T$ axis directions are reported in fig. 4 and we will take them into account in our discussion.

Each studied area is included in a box, and its dimensions are chosen on the basis of seismicity distribution and of the tectonic setting (fig. 2). For instance, the Northern Africa to Sicily zone is split into four sections because the strike of the boundary between Africa and Eurasia plates changes direction four times (fig. 1) and the geological setting shows that strike slip structures are mainly present immediately east of Gibraltar (section 1 in fig. 2) and in the area from Eastern Algerian to Tunisian Tell (section 3 in fig. 2), while thrust-related fold structures prevail in Northern Algeria and in the Tunisia to Sicily sections (sections 2 and 4 in fig. 2) (Meghraoui and Doumaz, 1996; Meghraoui and Pondrelli, 1996; Morel and Meghraoui, 1996). Going eastward, along the Apennines we compute the seismic deformation in two distinct sections (6 and 7 in fig. 2) because of the variation of the boundary direction. Actually, in Calabria it strikes NE-SW while along Central to Southern Apennines it is NWSE, but in both areas the present day active tectonic pattern is extensional (Valensise and Pantosti, 1992; Pantosti et al., 1993, 1996; Cucci et al., 1996). Going northward, the scarcity of strong seismicity along the boundary up to the Eastern Alps imposes the study of only the Friuli region, characterised by a quite $\mathrm{N}-\mathrm{S}$ compres-

Table I. Parameters used to measure each section. For section numbers see fig. 2 . The angle of rotation refers to the strike of each section from north.

\begin{tabular}{ccccc}
\hline \hline Section & $x(\mathrm{~km})$ & $y(\mathrm{~km})$ & $z(\mathrm{~km})$ & Rotation \\
\hline 1 & 540 & 250 & 15 & $255^{\circ}$ \\
2 & 520 & 250 & 15 & $255^{\circ}$ \\
3 & 550 & 250 & 15 & $255^{\circ}$ \\
4 & 560 & 250 & 15 & $255^{\circ}$ \\
5 & 700 & 250 & 15 & $130^{\circ}$ \\
6 & 240 & 100 & 15 & $210^{\circ}$ \\
7 & 630 & 170 & 15 & $135^{\circ}$ \\
8 & 300 & 130 & 15 & $265^{\circ}$ \\
9 & 700 & 130 & 15 & $135^{\circ}$ \\
\hline
\end{tabular}


sional tectonic regime (Anderson and Jackson, 1987; Slejko et al., 1987). This last section is separated from the Eastern Adriatic, again characterised by a compressional tectonic regime (Anderson and Jackson, 1987), because of the abrupt change from EW to NW-SE of the boundary direction. Parameters used to dimension each section are shown in table I.

\section{Geometry of deformation}

The cumulative moment tensors obtained from the summation are shown in fig. 3 and the corresponding $P$ and $T$ axes are shown in fig. 4 . The obtained geometry of deformation is in agreement with the pattern obtained in other studies, as geodetic evaluation of plate motion (Ward, 1994; Zarraoa et al., 1994) or studies of stress distribution in this area (Rebaï et al., 1992; Frepoli and Amato, 1997; Amato and Montone, 1997). Moreover our results show some interesting relations between changes in style and amount of deformation, as in the Northern Africa sections.

Starting from the Gibraltar Strait section (section 1 in fig. 2) and going east, we find prevailing strike slip and pure thrust deformation that alternate along the boundary up to the Messina Strait (fig. 3). This variation, typical of a dextral transpressive boundary, is also visible in the already described geological features (Morel and Meghraoui, 1996; Meghraoui and Pondrelli, 1996). The $P$ axes rotate from a NW-SE direction in the Gibraltar section to a N-S direction in

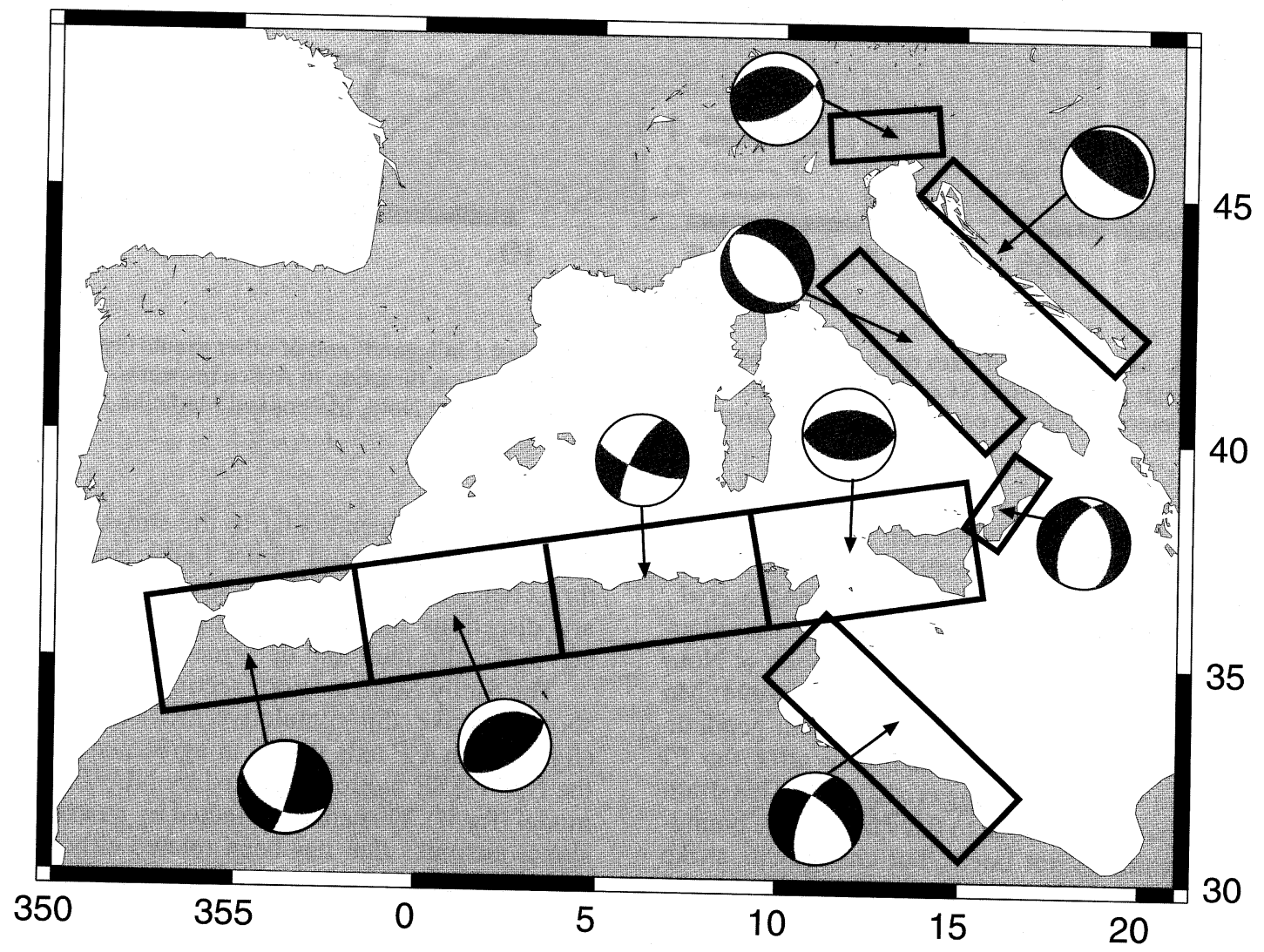

Fig. 3. Map of cumulative moment tensors. 


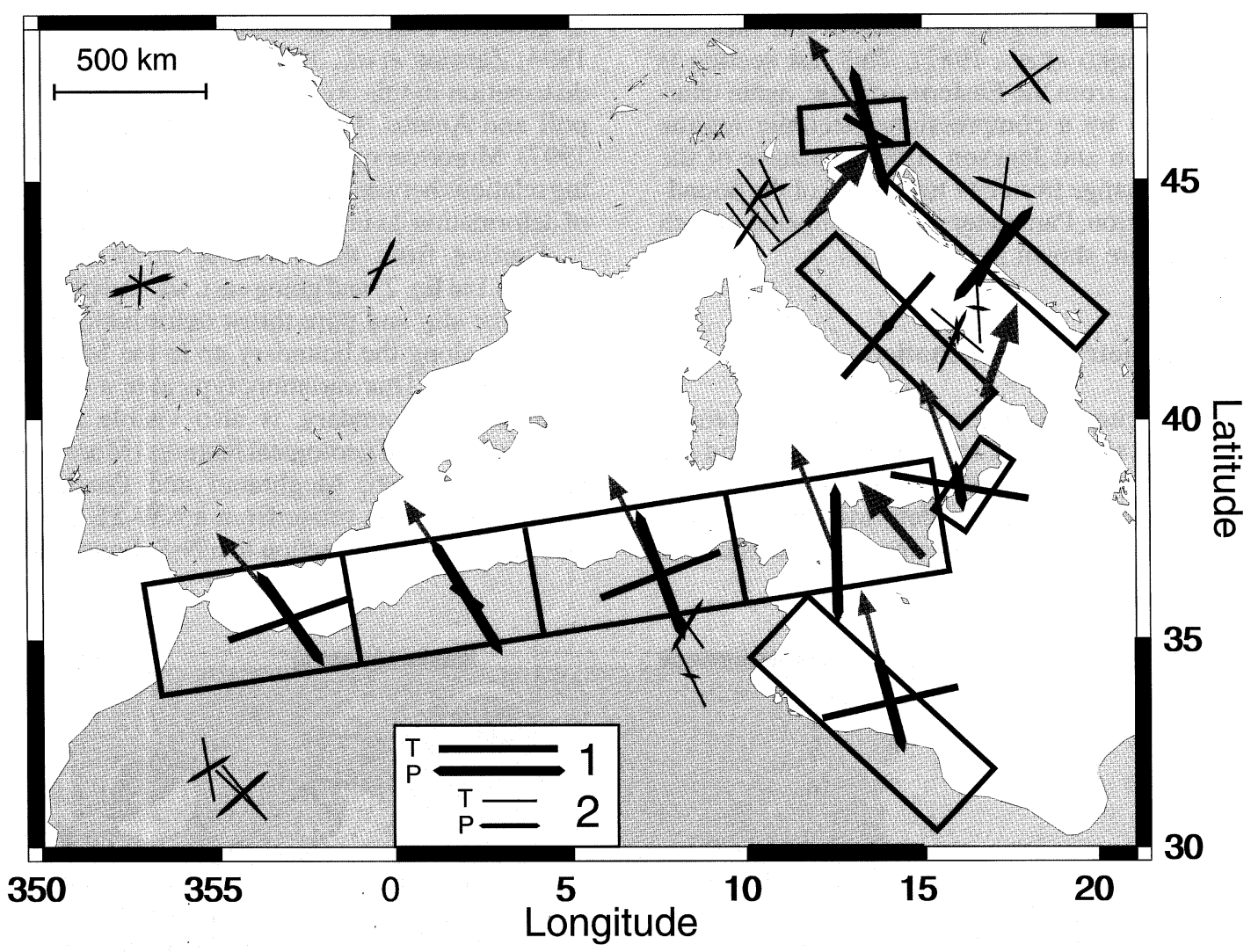

Fig. 4. Map of $P$ and $T$ axes of cumulative moment tensors (symbol 1 in legend) and of other events (symbol 2 in legend; listed in table XI.A). Thin grey arrows: NUVEL1A plate motion direction of Africa respect to Eurasia plate determined for in each section. Thick grey arrows: VLBI direction at Noto, Matera and Medicina sites.

the Tunisia to Sicily section (fig. 4), and are strongly in agreement with the NUVEL1A plate motion model (Argus et al., 1989; De Mets et al., 1990, 1994). They coarsely agree with the velocity vector computed for the VLBI point of Noto (Sicily) (Ward, 1994; Zarraoa et al., 1994; Ma and Ryan, 1998) and well agree with geodetic measurements done immediately after the El Asnam sequence (Ruegg et al., 1982). This strain distribution is related to the shape of the boundary, which is not linear, but changes its strike twice (from EW, in the Gibraltar Strait and in the Algeria to Tunisia sections, to NE, in the Algeria and Tunisia to Sicily sections), while the stress direction is constantly NW-SE: where the bound- ary is almost perpendicular to the stress direction we find folds and thrust faults and pure thrust deformation. Where the stress and boundary directions differ by an angle lower than $90^{\circ}$ strike slip fault and deformation prevail.

The Sicily Strait section (section 5 in fig. 2) shows a strike slip cumulative moment tensor (fig. 3) with a $P$ axis that is in agreement with the NNW-SSE motion expected by NUVEL1A model (fig. 4). This area is affected by an extensional tectonics that has been related either to the subduction still occurring in the Southern Tyrrhenian Sea (Argnani, 1990) or to a right transtensive system generated along the transpressive boundary between Africa and Eurasia 
(Cello, 1987). The strike slip cumulative moment tensor we obtain shows a better agreement with the transtensive hypothesis, but we should consider that the area affected by strong seismicity is the southern portion of the entire Sicily Strait tectonic area, and that most of the data shown to support the back-arc basin hypothesis have been observed in the northern part of the basin (Argnani, 1990).

For the Calabria and Central to Southern Apennines sections, as expected, the obtained geometry of deformation is extensional. In Calabria, the transition zone from the area where only Africa and Eurasia plates are involved in the boundary kinematics to the area where the presence of the Adria plate mostly influences the environment, the $P$ axis direction is still in agreement with NUVEL1A model, but the extensional deformation which characterises the Southern Apennines chain is already present (fig. 4). In the Central to Southern Apennines (section 7) a NE-SW extension is in agreement with stress orientation obtained from focal mechanisms of smaller earthquakes (Frepoli and Amato, 1997) and borehole breakout data (Amato and Montone, 1997), and it is even relatively in agreement with the VLBI directions of Medicina and Matera sites (Ma and Ryan, 1998; fig. 4).

Both in Friuli and in the Eastern Adriatic sections the cumulative moment tensors show a quite pure thrust deformation, with a $P$ axis in agreement with local compressive regimes (Alps and Dynarides chains) related to the convergence of Adria and Eurasia plates (Anderson and Jackson, 1987; Slejko et al., 1987).

\section{Seismic deformation}

The Western Mediterranean is characterized by a low rate of seismic to total expected deformation (Ward, 1998). We compared obtained seismic deformation with the total expected deformation, computed with plate velocities, where available, and the Jackson and McKenzie (1988) method. For most sections, where major plates are involved, we used, as reference for plate velocity, the NUVEL1A model, due to its continuity in space and its global validity. In Central to Southern Apennines and Eastern
Adriatic sections we used the velocity computed by Westaway (1992) for the Southern Apennines, $0.5 \mathrm{~mm} / \mathrm{yr} 40^{\circ} \mathrm{NE}$, evaluated on historical seismicity. Using this value we underestimate the real total deformation, but in this area NUVEL1A velocities are not representative because global plate motion models do not include microplate motions, as for the Adria plate. The percentages resulting from these comparisons are in any case the upper values of the seismic deformation contribution.

Comparing total and seismic deformation along the Northern Africa to Sicily sections, we find an interesting relation between geometry and amount of deformation due to seismicity. Within sections affected by pure thrust motion we find a higher seismic deformation ( $26 \%$ for the Algeria section and $10 \%$ for the Tunisia to Sicily section) with respect to the sections where the strike-slip motion prevails, characterized instead by very small percentages of seismic deformation $(<1 \%)$.

For all sections, however, the seismicity accounts for low percentages of total expected deformation normal to the boundary: $31 \%$ in the Calabria section, $30 \%$ in the Central to Southern Apennine section, 3\% in the Friuli section and $10 \%$ in the Eastern Adriatic section. Only in the Sicily Strait section do we find a high value of strain accommodated by seismicity that here accounts for $79 \%$ of total strike slip deformation.

It is clear that these values are generally low, but comparable values have also been found in this area (Jackson and McKenzie, 1988; Pondrelli et al., 1995; Ward, 1998). We assume that these small percentages are due to the fact that 90 years are not representative of the seismic recurrence cycle of these zones, as already suggested by Ward (1998). However, more and more studies are showing that aseismic deformation is effectively high and often related to silent events (or slow earthquakes) (Amoruso et al., 1998; Hirose et al., 1998; Linde et al., 1996, 1998).

\section{Discussion}

In a general view of $P$ and $T$ axes of cumulative moment tensors and other sparse events (fig. 4), it is clear that seismic deformation di- 
rection is mostly in agreement with the plate motion expected in the Western Mediterranean by NUVEL1A model and geodetic measurements. But NUVEL1A cannot be used as a reference in the Periadriatic area, due to the fact that microplate motions are not included in this model. Moreover, VLBI measurements of the same area have been frequently discussed for the uncertainties on the tectonic setting of the site's location and on the significance of reference systems within which directions are computed (Mantovani et al., 1995).

The geometry of deformation deduced from seismicity maps a sketch continuous enough of the strain pattern from Gibraltar Strait to Eastern Adriatic area (fig. 4). Only along the Alps the strong seismicity, representative of regional stress, is insufficient to deduce a clear tectonic pattern. Moreover, in the Northern Apennines, that in the last century was affected by only four strong earthquakes with different focal mechanisms (two are extensional and two are strike slip; table VIII.A and fig. 4), it is difficult to apply the moment tensor summation. The heterogeneity of the deformation of this area has been confirmed studying smaller events that demonstrated the co-existence of contemporaneous extensional and compressive stress regime (Frepoli and Amato, 1997).

Studying the geometry of seismic deformation, it is possible to enhance local and regional features, different from global motion, usually computed at a greater scale. Along the Northern Africa to Sicily sections, typical transpressive boundary characteristics have been shown where a simple compressional boundary is expected from global models. In the Central to Southern Apennines and the Eastern Adriatic sections, the geometry of seismic deformation shows that both areas are directly involved in the evolution of the peri-Tyrrhenian region, where the slab retreated and the opening of the Tyrrhenian basin produced an eastward migration (Malinverno and Ryan, 1986) and the probable rotation of the Adria plate (Anderson and Jackson, 1987). The consequent NE-SW prevailing strain pattern overprints the NNW-SSE Africa Eurasia plate convergence.

\section{Conclusions}

The moment tensor summation method was applied in the Western Mediterranean using data accounting for 90 years of intermediate to strong earthquakes $(M \geq 4.5)$. The seismic deformation was computed for nine sections selected on the basis of seismicity distribution and main tectonic features. The results obtained were compared with NUVEL1A plate motion velocities and geodetic measurements. A good agreement was found along the Northern Africa to Sicily sections between the computed geometry of deformation and the NUVEL1A global model. Along periadriatic sections, where NUVEL1A does not apply, seismic deformation well agreed with available VLBI data. From the comparison between seismic to total expected deformation, percentages ranging from 3 to $31 \%$ of strain accommodated by seismicity were found. Only in the Strait of Sicily section did the strike slip seismic deformation account for the $79 \%$. We still do not know if aseismic deformation may reach these high values, and we should remember that 90 years may be not representative of the characteristic seismicity recurrence of Western Mediterranean area. In any case, the amount of seismic deformation is lower than expected, but the obtained strain pattern shows few interesting features that global plate motion and geodetic measurements do not disclose, such as the transpressive pattern along the Northern Africa to Sicily zone or the influence of the peri-Tyrrhenian area evolution on the present deformation of periadriatic sections.

\section{Acknowledgements}

The author wishes to thank Mustapha Meghraoui for stimulating and useful discussions. I am grateful to Andrea Morelli and Claudia Piromallo for constructive comments and annotations. This research made use of NASA Goddard Space Flight Center's VLBI terrestrial reference frame solution number $1083 \mathrm{c}, 1997 \mathrm{Au}-$ gust, recovered from web site http://lupus.gsfc. nasa.gov/vlbi.html. 


\section{Appendix - Tables of used data}

Table I.A. Data set used in the Gibraltar Strait section. Reference: MM = Morel and Meghraoui (1996).

\begin{tabular}{cccccc}
\hline Day & Lat. & Long. & Depth & $m_{b}$ & Ref. \\
\hline $08 / 23 / 59$ & 35.50 & -3.20 & 20.0 & 5.5 & MM \\
$11 / 15 / 64$ & 34.90 & -5.40 & 8.0 & 5.0 & MM \\
$04 / 17 / 68$ & 35.20 & -4.20 & 13.0 & 5.0 & MM \\
$04 / 07 / 70$ & 34.90 & -3.90 & 27.0 & 4.8 & MM \\
$07 / 02 / 71$ & 34.00 & -5.20 & 11.0 & 4.6 & MM \\
$11 / 22 / 72$ & 36.00 & -4.00 & 19.0 & 4.4 & MM \\
$04 / 29 / 73$ & 34.60 & -4.20 & 35.0 & 4.5 & MM \\
$08 / 24 / 73$ & 35.90 & -1.80 & 1.0 & 5.5 & MM \\
$07 / 14 / 74$ & 35.60 & -3.70 & 2.0 & 4.3 & MM \\
$11 / 24 / 83$ & 34.00 & -5.20 & 27.0 & 4.6 & MM \\
$12 / 23 / 93$ & 36.77 & -2.99 & 20.0 & 5.0 & CMT Cat. \\
$05 / 26 / 94$ & 35.37 & -4.12 & 10.0 & 5.7 & CMT Cat. \\
\hline
\end{tabular}

Table II.A. Data set used in the Algeria section. Reference: JMK88 = Jackson and McKenzie (1988);
MM = Morel and Meghraui (1996).

\begin{tabular}{cccccl}
\hline \hline Day & Lat. & Long. & Depth & $m_{b}$ & Ref. \\
\hline $09 / 09 / 54$ & 36.30 & 1.50 & 15.0 & 6.5 & JMK88 \\
$09 / 10 / 54$ & 36.30 & 1.50 & 15.0 & 6.0 & JMK88 \\
$07 / 13 / 67$ & 35.50 & -0.10 & 23.0 & 5.1 & MM \\
$04 / 23 / 67$ & 36.20 & 2.40 & 28.0 & 4.8 & MM \\
$10 / 10 / 80$ & 36.20 & 1.35 & 10.0 & 6.5 & CMT Cat. \\
$10 / 10 / 80$ & 36.22 & 1.61 & 10.0 & 6.2 & CMT Cat. \\
$10 / 13 / 80$ & 36.26 & 1.57 & 10.0 & 5.2 & CMT Cat. \\
$10 / 30 / 80$ & 36.30 & 1.60 & 10.0 & 5.1 & MM \\
$11 / 08 / 80$ & 36.11 & 1.36 & 10.0 & 5.3 & CMT Cat. \\
$12 / 05 / 80$ & 35.95 & 1.37 & 10.0 & 5.0 & CMT Cat. \\
$12 / 07 / 80$ & 36.03 & 1.23 & 10.0 & 5.3 & CMT Cat. \\
$01 / 15 / 81$ & 36.36 & 1.64 & 10.0 & 5.0 & CMT Cat. \\
$02 / 01 / 81$ & 36.44 & 1.66 & 10.0 & 5.5 & CMT Cat. \\
$02 / 14 / 81$ & 35.90 & 1.28 & 10.0 & 5.0 & CMT Cat. \\
$11 / 15 / 82$ & 35.63 & 1.32 & 10.0 & 5.0 & CMT Cat. \\
$10 / 31 / 88$ & 36.35 & 2.73 & 10.0 & 5.3 & CMT Cat. \\
$10 / 29 / 89$ & 36.79 & 2.45 & 10.0 & 5.8 & CMT Cat. \\
$02 / 09 / 90$ & 36.75 & 2.43 & 12.0 & 5.0 & CMT Cat. \\
$08 / 18 / 94$ & 35.56 & -0.11 & 9.0 & 5.5 & CMT Cat. \\
\hline
\end{tabular}


Table III.A. Data set used for the Algeria-Tunisia boundary. References: see table I.A.

\begin{tabular}{cccccl}
\hline \hline Day & Lat. & Long. & Depth & $m_{b}$ & Ref. \\
\hline $01 / 01 / 65$ & 36.17 & 4.67 & 10.0 & 5.2 & MM \\
$08 / 28 / 77$ & 38.21 & 8.21 & 10.0 & 5.1 & CMT Cat. \\
$10 / 27 / 85$ & 36.20 & 6.75 & 10.0 & 5.5 & CMT Cat. \\
$09 / 04 / 96$ & 36.98 & 2.88 & 10.0 & 5.3 & CMT Cat. \\
\hline
\end{tabular}

Table IV.A. Data set used in the Tunisia to Sicily section. Reference: JMK88 = Jackson and McKenzie (1988); AJ87 = Anderson and Jackson (1987).

\begin{tabular}{cccccl}
\hline \hline Day & Lat. & Long. & Depth & $m_{b}$ & Ref. \\
\hline $03 / 16 / 41$ & 38.30 & 12.20 & 15.0 & 6.9 & JMK88 \\
$01 / 15 / 68$ & 37.75 & 12.98 & 10.0 & 5.4 & AJ87 \\
$01 / 16 / 68$ & 37.85 & 12.98 & 36.0 & 5.1 & AJ87 \\
$01 / 25 / 68$ & 37.68 & 12.97 & 3.0 & 5.1 & AJ87 \\
$04 / 15 / 78$ & 38.39 & 15.07 & 14.0 & 5.5 & CMT Cat. \\
$12 / 08 / 79$ & 38.28 & 11.74 & 33.0 & 5.4 & CMT Cat. \\
$05 / 28 / 80$ & 38.48 & 14.25 & 14.0 & 5.7 & CMT Cat. \\
$12 / 13 / 90$ & 37.20 & 15.50 & 10.0 & 5.4 & CMT Cat. \\
\hline
\end{tabular}

Table V.A. Data set used in Sicily Strait region. Reference: W90 = Westaway (1990).

\begin{tabular}{cccccc}
\hline \hline Day & Lat. & Long. & Depth & $m_{b}$ & Ref. \\
\hline $09 / 04 / 74$ & 33.10 & 13.58 & 17.0 & 5.6 & W90 \\
$04 / 19 / 35$ & 31.00 & 15.20 & 30.0 & 7.0 & W90 \\
$03 / 26 / 88$ & 33.20 & 13.34 & 10.0 & 4.8 & CMT Cat. \\
$01 / 03 / 89$ & 35.50 & 11.66 & 10.0 & 5.0 & CMT Cat. \\
$11 / 11 / 90$ & 33.94 & 12.04 & 10.0 & 4.7 & CMT Cat. \\
$06 / 12 / 92$ & 34.15 & 8.34 & 10.0 & 5.3 & CMT Cat. \\
$09 / 10 / 93$ & 35.00 & 12.40 & 10.0 & 4.8 & CMT Cat. \\
\hline
\end{tabular}

Table VI.A. Data set used for Calabria section. Reference: JMK88 = Jackson and McKenzie (1988).

\begin{tabular}{cccccl}
\hline \hline Day & Lat. & Long. & Depth & $m_{b}$ & \multicolumn{1}{c}{ Ref. } \\
\hline $12 / 28 / 1908$ & 38.20 & 15.60 & 15.0 & 7.0 & JMK88 \\
$03 / 11 / 1978$ & 38.10 & 16.03 & 33.0 & 5.6 & CMT Cat. \\
\hline
\end{tabular}


Table VII.A. Data set used for the Central to Southern Apennines section. $M_{w}$ are fromEkström et al. (1998). Reference: JMK88 = Jackson and McKenzie (1988); EMBD98 = Ekström et al. (1998).

\begin{tabular}{|c|c|c|c|c|c|}
\hline Day & Lat. & Long. & Depth & $m_{b}$ & Ref. \\
\hline $01 / 13 / 15$ & 42.00 & 13.60 & 15.0 & 6.8 & JMK88 \\
\hline $07 / 23 / 30$ & 41.10 & 15.40 & 15.0 & 6.5 & JMK88 \\
\hline $09 / 19 / 79$ & 42.81 & 13.06 & 16.0 & 5.9 & CMT Cat. \\
\hline $11 / 23 / 80$ & 40.91 & 15.37 & 10.0 & 6.0 & CMT Cat. \\
\hline $11 / 25 / 80$ & 40.39 & 15.40 & 10.0 & 4.9 & CMT Cat. \\
\hline $01 / 16 / 81$ & 40.95 & 15.37 & 15.0 & 5.0 & CMT Cat. \\
\hline $04 / 29 / 84$ & 43.27 & 12.57 & 14.0 & 5.2 & CMT Cat. \\
\hline 05/07/84 & 41.77 & 13.89 & 10.0 & 5.5 & CMT Cat. \\
\hline $05 / 11 / 84$ & 41.83 & 13.95 & 13.0 & 5.3 & CMT Cat. \\
\hline $05 / 05 / 90$ & 40.75 & 15.85 & 26.0 & 5.3 & CMT Cat. \\
\hline 09/03/97 & 43.01 & 12.90 & 10.2 & $4.5\left(M_{w}\right)$ & EMBD98 \\
\hline $09 / 26 / 97$ & 43.02 & 12.89 & 10.0 & $5.7\left(M_{w}\right)$ & EMBD98 \\
\hline $09 / 26 / 97$ & 43.03 & 12.85 & 10.0 & $6.0\left(M_{w}\right)$ & EMBD98 \\
\hline 09/26/97 & 43.01 & 12.97 & 10.0 & $4.5\left(M_{w}\right)$ & EMBD98 \\
\hline 09/27/97 & 43.09 & 12.81 & 5.5 & $4.3\left(M_{w}\right)$ & EMBD98 \\
\hline $10 / 03 / 97$ & 43.03 & 12.84 & 10.0 & $5.2\left(M_{w}\right)$ & EMBD98 \\
\hline $10 / 04 / 97$ & 42.94 & 12.93 & 10.0 & $4.7\left(M_{w}\right)$ & EMBD98 \\
\hline $10 / 06 / 97$ & 43.02 & 12.84 & 10.0 & $5.4\left(M_{w}\right)$ & EMBD98 \\
\hline $10 / 07 / 97$ & 42.99 & 12.82 & 11.6 & $4.2\left(M_{w}\right)$ & EMBD98 \\
\hline $10 / 07 / 97$ & 43.03 & 12.85 & 10.0 & $4.5\left(M_{w}\right)$ & EMBD98 \\
\hline $10 / 12 / 97$ & 42.91 & 12.94 & 10.0 & $5.2\left(M_{w}\right)$ & EMBD98 \\
\hline $10 / 14 / 97$ & 42.93 & 12.92 & 10.0 & $5.6\left(M_{w}\right)$ & EMBD98 \\
\hline $10 / 16 / 97$ & 43.04 & 12.89 & 10.0 & $4.3\left(M_{w}\right)$ & EMBD98 \\
\hline $10 / 19 / 97$ & 42.97 & 12.79 & 10.0 & $4.2\left(M_{w}\right)$ & EMBD98 \\
\hline
\end{tabular}
Table VIII.A. Strong events which occurred in the last century in the Northern Apennines. Reference:
JMK88 = Jackson and McKenzie (1988).

\begin{tabular}{cccccc}
\hline Day & Lat. & Long. & Depth & $m_{b}$ & Ref. \\
\hline $06 / 29 / 19$ & 44.00 & 11.50 & 15.0 & 6.2 & JMK88 \\
$09 / 07 / 20$ & 44.30 & 10.30 & 15.0 & 6.3 & JMK88 \\
$11 / 09 / 83$ & 44.69 & 10.32 & 37.0 & 5.1 & CMT Cat. \\
$10 / 15 / 96$ & 44.79 & 10.78 & 10.0 & 5.3 & CMT Cat. \\
\hline
\end{tabular}


Table IX.A. Data set used for the Friuli section. Reference: PMEV98 = Pondrelli et al. (1998).

\begin{tabular}{ccccccc}
\hline \hline Day & Time & Lat. & Long. & Depth & $m_{b}$ & Ref. \\
\hline $06 / 17 / 76$ & $14: 28: 58.3$ & 46.05 & 12.50 & 45.5 & 6.1 & CMT Cat. \\
$05 / 06 / 76$ & $20: 00: 19.3$ & 46.15 & 13.39 & 10.0 & 6.8 & PMEV98 \\
$05 / 07 / 76$ & $00: 23: 53.8$ & 46.24 & 13.32 & 10.0 & 4.9 & PMEV98 \\
$05 / 09 / 76$ & $00: 53: 47.9$ & 46.06 & 13.49 & 10.0 & 5.1 & PMEV98 \\
$05 / 11 / 76$ & $22: 44: 02.1$ & 46.00 & 13.04 & 10.0 & 5.0 & PMEV98 \\
$09 / 11 / 76$ & $16: 31: 15.3$ & 46.40 & 13.50 & 10.0 & 5.2 & PMEV98 \\
$09 / 11 / 76$ & $16: 35: 04.8$ & 46.15 & 13.34 & 10.0 & 5.6 & PMEV98 \\
$09 / 15 / 76$ & $03: 15: 23.5$ & 46.18 & 13.27 & 10.0 & 5.9 & PMEV98 \\
$09 / 15 / 76$ & $09: 21: 22.7$ & 46.20 & 13.23 & 10.0 & 6.0 & PMEV98 \\
$09 / 16 / 77$ & $23: 48: 09.9$ & 46.18 & 12.82 & 12.0 & 5.2 & PMEV98 \\
$04 / 18 / 79$ & $15: 19: 22.9$ & 46.40 & 13.16 & 10.0 & 4.7 & PMEV98
\end{tabular}

Table X.A. Data set used for the Eastern Adriatic section. Reference: MK72 = McKenzie (1972); JMK88 = Jackson and McKenzie (1988).

\begin{tabular}{cccccl}
\hline \hline Day & Lat. & Long. & Depth & $m_{b}$ & Ref. \\
\hline $03 / 15 / 23$ & 43.30 & 17.10 & 15.0 & 6.2 & JMK88 \\
$02 / 14 / 27$ & 43.00 & 18.20 & 15.0 & 6.0 & JMK88 \\
$10 / 18 / 36$ & 46.08 & 12.83 & 18.0 & 5.6 & MK72 \\
$12 / 29 / 43$ & 43.40 & 17.20 & 15.0 & 6.0 & JMK88 \\
$04 / 09 / 79$ & 41.96 & 19.02 & 10.0 & 5.3 & CMT Cat. \\
$04 / 15 / 79$ & 42.04 & 19.05 & 10.0 & 5.7 & CMT Cat. \\
$04 / 15 / 79$ & 42.32 & 19.68 & 4.0 & 6.1 & CMT Cat. \\
$05 / 24 / 79$ & 42.26 & 18.75 & 8.0 & 5.8 & CMT Cat. \\
$05 / 13 / 84$ & 42.93 & 17.73 & 10.0 & 5.2 & CMT Cat. \\
$11 / 21 / 85$ & 41.72 & 19.32 & 22.0 & 5.4 & CMT Cat. \\
$03 / 03 / 86$ & 41.95 & 19.27 & 23.0 & 5.0 & CMT Cat. \\
$11 / 25 / 86$ & 44.14 & 16.41 & 27.0 & 5.3 & CMT Cat. \\
$11 / 27 / 90$ & 43.87 & 16.63 & 10.0 & 5.2 & CMT Cat. \\
$09 / 28 / 95$ & 42.65 & 18.09 & 10.0 & 5.1 & CMT Cat. \\
$09 / 05 / 96$ & 42.80 & 17.94 & 10.0 & 5.6 & CMT Cat. \\
$09 / 09 / 96$ & 42.77 & 17.87 & 10.0 & 4.8 & CMT Cat. \\
$09 / 17 / 96$ & 42.87 & 17.82 & 10.0 & 5.4 & CMT Cat. \\
\hline
\end{tabular}


Table XI.A. Other events. References: see table X.A.

\begin{tabular}{ccrrrll}
\hline \hline Day & Lat. & Long. & Depth & $m_{b}$ & \multicolumn{1}{c}{ Ref. } & \multicolumn{1}{c}{ Region } \\
\hline $08 / 21 / 62$ & 41.67 & 15.83 & 34.0 & 6.0 & MK72 & Southern Apennines \\
$02 / 29 / 80$ & 43.26 & -0.34 & 10.0 & 4.9 & CMT Cat. & Pyrenees \\
$08 / 13 / 81$ & 44.86 & 17.33 & 9.0 & 5.5 & CMT Cat. & In. Dynarides sec. \\
$08 / 15 / 85$ & 47.05 & 18.06 & 10.0 & 4.8 & CMT Cat. & Pannonian Basin \\
$01 / 28 / 86$ & 31.92 & -5.35 & 10.0 & 4.9 & CMT Cat. & Morocco \\
$04 / 26 / 88$ & 42.37 & 16.57 & 24.0 & 5.3 & CMT Cat. & Adriatic Sea \\
$06 / 12 / 92$ & 34.15 & 8.34 & 10.0 & 5.3 & CMT Cat. & Tunisia \\
$10 / 23 / 92$ & 31.35 & -4.33 & 28.0 & 5.2 & CMT Cat. & Morocco \\
$10 / 30 / 92$ & 31.30 & -4.43 & 25.0 & 5.1 & CMT Cat. & Morocco \\
$09 / 22 / 95$ & 35.33 & 8.25 & 10.0 & 4.7 & CMT Cat. & Tunisia \\
$09 / 30 / 95$ & 41.90 & 15.97 & 10.0 & 5.2 & CMT Cat. & Gargano Prom. \\
$05 / 21 / 97$ & 42.88 & -7.19 & 19.0 & 4.9 & CMT Cat. & Pyrenees \\
$05 / 21 / 97$ & 42.90 & -7.13 & 19.0 & 5.3 & CMT Cat. & Pyrenees \\
\hline
\end{tabular}

\section{REFERENCES}

Amato, A. and P. MonTone (1997): Present-day stress field and active tectonics in Southern Peninsular Italy, Geophys. J. Int., 130, 519-534.

AMoruso, A., L. CRESCENTINI and R. SCARPA (1998): Slow earthquakes and seismicity in Central Italy, $A G U$ abstract volume, F606.

ANDERSON, H. and J. JACKSON (1987): Active tectonics in the Adriatic region, Geophys. J. R. Astron. Soc., 91, 937-983.

Anzidei, M., P. Baldi, G. Casula, S. Pondrelli, F. RiguZZI and A. ZANUTTA (1997): Geodetic and seismological investigation in the Ionian area, Ann. Geofis., 40 (5), 1007-1017.

ARGNANI, A. (1990): The Strait of Sicily rift zone: foreland deformation related to the evolution of a back-arc basin, J. Geodyn., 12, 311-331.

ARguS, D.F., R.G. Gordon, C. DeMETS and S. SteIN (1989): Closure ofthe Africa-Eurasia-North America plate motion circuit and tectonics of the Gloria fault, J. Geophys. Res., 94, 5585-5602.

CELLO, G. (1987): Structure and deformation processes in the Strait of Sicily «rift zone», Tectonophysics, 141, 237-247.

Cucci, L., G. D'Addezio, G. VALEnsise and P. Burrato (1996): Investigating seismogenic faults in Central and Southern Apennines (Italy): modeling of fault-related landscape features, Ann. Geofis., 39 (3), 603-618.

DeMeTS, C., R.G. Gordon, D.F. ARGUS and S. STEIN (1990): Current plate motions, Geophys. J. Int., 101,
425-478.
DeMets, C., R.G. Gordon, D.F. Argus and S. SteIN (1994): Effect of recent revisions to the geomagnetic reversal time scale on estimate of current plate motions, Geophys. Res. Lett., 21 (20), 2191-2194.

Dewey, J.F., M.L. Helman, E. TurCo, D.H.W. Hutron and S.D. KNOTT (1989): Kinematics of Western Mediterranean, in Alpine Tectonics, edited by M.P. CowARD, D. Detrich and R.G. PARK, Geol. Soc. London, Spec. Publ., 45, 265-283.

DZIEWONSKI, A.M., A. FrIEDMAN, D. GIARDINI and J.H. WOODHOUSE (1983): Global seismicity of 1982: centroid moment tensor solutions for 308 earthquakes, Phys. Earth Planet. Inter., 53, 17-45.

EKSTRÖM, G. and P. ENGLAND (1989): Seismic strain rates in regions of distributed continental deformation, J. Geophys. Res., 94, 10231-10257.

EkströM, G., A. MORElli, E. BosChi and A.M. DZIEWONSKI (1998): Moment tensor analysis of the Central Italy earthquake sequence of SeptemberOctober 1997, Geophys. Res. Lett., 25, 1971-1974.

FrePOLI, A. and A. AMATO (1997): Contemporaneous extension and compression in the Northern Apennines from earthquake fault-plane solutions, Geophys. J. Int., 129, 368-388.

Hirose, I., I. KaWASAKI, Y. OKadA, T. SAGIYA and Y. TAMURA (1998): An $M 6$ class interplate silent earthquake of December 9, 1989, as revealed by borehole observations of the crutal movement in the South Kanto District, Central Japan, AGU abstract volume, F601.

JACKSON, J. and D.P. MCKENZIE (1988): The relationship between plate motions and seismic moment tensors, 
and the rates of active deformation in the Mediterranean and Middle East, Geophys. J. Int., 93, 45-73.

KostroV, V.V. (1974): Seismic moment and energy of earthquakes and seismic flow of rocks, Izv. Acad. Sci., USSR, Phys. Solid Earth, 1, 23-44.

LINDE, A.T., M.T. Gladwin, M.J.S. Johnston, R.L. GWYTHER and R.G. BILHAM (1996): A slow earthquake sequence on the San Andreas fault, Nature, 383, 65-68.

LINDE, A.T., I.S. SACKS, M.T. GLADWIN, M.J.S. JOHNSTON and P.G. SILVER (1998): Slow earthquakes at plate boundaries - a connection with large earthquakes? AGU abstract volume, F600.

MA, C. and J.W. RYAN (1998): NASA Space Geodesy Program - GSFC DATA Analysis - 1998, VLBI Geodetic Results 1979-1998, August 1998, http:// lupus.gsfc.nasa.gov

MALINVERNO, A. and W.B.F. RYAN (1986): Extension in the Tyrrhenian Sea and shortening in the Apennines as result of arc migration driven by sinking of the lithosphere, Tectonics, 5, 227-245.

Mantovani, E., D. Albarello, C. Tamburelli and M. VITI (1995): Tectonic interpretation of large scale geodetic measurements (VLBI, SRL) in the Central Mediterranean region: constraints and uncertainties, Ann. Geofis., 38 (1), 67-84.

MCKENZIE, D.P. (1972): Active tectonics of the Mediterranean region, Geophys. J. R. Astron. Soc., 30, 109-185.

MeghraOUI, M. and F. DouMAZ (1996): Earthquakeinduced flooding and paleoseismicity of the El Asnam, Algeria, fault-related fold, J. Geophys. Res., 101, 17617-17644.

MeghraOUI, M. and S. PONDRELLI (1996): Transpression and block rotation along the plate boundary in North Africa, in ESC XXV General Assembly, Reykjavik, abstract volume, p. 11.

MOREL, J.L. and M. MEGHRAOUI (1996): The GoringeAlboran-Tell (GALTEL) tectonic zone, a transpression system along the Africa-Eurasia plate boundary, Geology, 24, 755-758.

PANTOSTI, D., D.P. SCHWARTZ and G. VALENSISE (1993): Paleoseismology along the 1980 surface rupture of the Irpinia fault: implications for earthquake recurrence in the Southern Apennines, Italy, J. Geophys. Res., 98, 6561-6577.

Pantosti, D., G. D'AdDezio and F.R. CinTI (1996): Paleoseismicity of the Ovindoli-Pezza fault, Central Apennines, Italy: a history including a large, previously unrecorded earthquake in the Middle Ages (860-1300 A.D.), J. Geophys. Res., 101, 5937-5959.

PAPAZACHOS, C.B. and A. KIRATZI (1992): A formulation for reliable estimation of active crustal deformation and its application to Central Greece, Geophys. J. Int., 111, 424-432.

Piromallo, C. and A. Morelli (1997): Imaging the
Mediterranean upper mantle by $P$-wave travel time tomography, Ann. Geofis., 40 (4), 963-979.

PONDRELLI, S., A. MORELLI and E. BOSCHI (1995): Seismic deformation in the Mediterranean area estimated by moment tensor summation, Geophys. J. Int., 122, 938-952.

Pondrelli, S., A. MORELli and G. EKSTRÖM (1998): Moment tensors and seismotectonics of the Mediterranean region, Ann. Geophys., 16 (suppl.), C19.

RebaÏ, S., H. PHILIP and A. TABOADA (1992): Modern tectonic stress field in the Mediterranean region: evidence for variation in stress directions at different scales, Geophys. J. Int., 110, 106-140.

RuEGG, J.C., M. KASSER, A. TARANTOLA, J.C. LEPINE and B. CHOUIKRAT (1982): Deformations associated with the El Asnam earthquake of 10 October 1980: geodetic determination of vertical and horizontal movements, Bull. Seismol. Soc. Am., 72, 2227-2244.

SelvagGi, G. and A. AmAto (1992): Subcrustal earthquakes in the Northern Apennines (Italy): evidence for still active subduction?, Geophys. Res. Lett., 19, 21272130.

Slejko, D., G.B. Carol, F. Carer, D. Castaldini, A. Cavallin, C. Doglioni, V. Illiceto, R. NiCOlich, A. REBEZ, E. SEMENZA, A. ZANFERRARI and C. ZANOLLA (1987): Modello sismotettonico dell'Italia NordOrientale, GNDT-CNR, Rend. No. 1, pp. 82.

SPAKMAN, W., S. VAN DER LEE and R. VAN DER HILST (1993): Travel-time tomography of the EuropeanMediterranean mantle down to $1400 \mathrm{~km}$, Phys. Earth Planet. Int., 79, 3-74.

VALENSISE, G. and D. PANTOSTI (1992): A 125-Kyr-long geological record of seismic source repeatability: the Messina Straits (Southern Italy) and the 1908 earthquake (Ms 7.5), Terra Nova, 4, 472-483.

WARD, S.N. (1994): Constraints on the seismotectonics of the Central Mediterranean from very long baseline interferometry, Geophys. J. Int., 117, 441-452.

WARD, S.N. (1998): On the consistency of earthquake moment release and space geodetic strain rates: Europe, Geophys. J. Int., 135, 1011-1018.

WESTAWAY, R. (1990): The Tripoli, Libya, earthquake of September 4, 1974: implications for the active tectonics of the Central Mediterranean, Tectonics, 9, 231-248.

WESTAWAY, R. (1992): Seismic moment summation for historical earthquakes in Italy: tectonic implications, J. Geophys. Res., 97, 15437-15464.

ZARRAOA, N., A. RIUS., E. SARDON and J.W. RYAN (1994): Relative motion in Europe studied with a geodetic VLBI network, Geophys. J. Int., 117, 763-768.

(received September 8, 1998; accepted January 15,1999$)$ 